P H I L I P S T E C H N I C A L L I B R A R Y

\title{
ELECTRICITY IN CARS
}

R. H. BACON

Second Edition

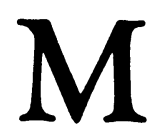


(C) N. V. Philips' Gloeilampenfabrieken, Eindhoven, 1967, 1975, 1976

All rights reserved. No part of this publication may be reproduced or transmitted, in any form or by any means, without permission.

First edition 1967

Paperback edition 1975

Second edition 1976

Published by

THE MACMILLAN PRESS LIMITED

London and Basingstoke

Associated companies in New York Dublin

Melbourne Johannesburg and Madras

ISBN 978-0-333-21378-0 ISBN 978-1-349-03176-4 (eBook)

DOI 10.1007/978-1-349-03176-4

No representation or warranty is given that the matter treated in this book is free from patent rights; nothing herein should be interpreted as granting, by implication or otherwise, a licence under any patent rights.

This book is sold subject to the standard conditions of the Net Book Agreement.

The paperback edition of this book is sold subject to the condition that it shall not, by way of trade or otherwise, be lent, resold, hired out, or otherwise circulated without the publisher's prior consent in any form of binding or cover other than that in which it is published and without a similar condition including this condition being imposed on the subsequent purchaser. 


\section{PREFACE}

This book has been written for the use of the automotive electrical engineer, fitter, mechanic and student whose career is concerned with the electrical system of the motor car. It is also intended for the keen driver who wishes to obtain full information, not only on how the system works, but also on why it works and why certain features are used in preference to others.

The basic principles of electricity and its application to the motor car are fully covered with the accent on principles of operation, with suitable illustrations of modern practice. Every endeavour has been made to make this volume as up-to-date as possible despite the continual development taking place in the industry. Despite this development, the basic principles still remain the same and with this knowledge, the newest developments can easily be followed.

In conclusion, the author trusts that the reader will find this work both informative and readable. If this is so, his endeavours will have succeeded.

R. H. Bacon 


\section{CONTENTS}

Chapter 1: ELECTRICAL THEORY . . . . . . . . . 1

The electric sections . . . . . . . . . . 1

The electric circuit . . . . . . . . . 2

Ohm's law ............... 3

The ampere-hour ........... . . . 4

Electric power ............. . . . 4

Conducting and insulating ........ . . 4

Magnetism ............. . . 5

Electromagnetism . . . . . . . . . 6

Electromagnetic induction . . . . . . . . 7

Generating electricity .......... . . 7

Generating direct current . . . . . . . . . 9

Dynamo or alternator? . . . . . . . . . 10

The direct current motor . . . . . . . . . 11

The induction coil . . . . . . . . . . 11

Self-induction and the condenser $\ldots . . . .12$

Chapter 2: WIRING . . . . . . . . . . . 13

The conductors ............. 13

Current return. . . . . . . . . 15

The wiring diagram. . . . . . . . . . 17

Connectors . . . . . . . . . . 17

Wiring troubles ............. 19

Fuses ............. 20

Chapter 3: THE BATTERY. . . . . . . . . . . 22

Primary and secondary cells . . . . . . . 22

The lead-acid battery . . . . . . . . . . 23

The plates and separators . . . . . . . . . 24

Battery chemistry ... . . . . . . . . 25

Checking battery charge. . . . . . . . . 26

Battery capacity . . . . . . . . . . . . 28

Maintaining the battery . . . . . . . . . 28

Charging the battery .......... . . 30

Battery chargers . . . . . . . . . . 31 
Chapter 4: CHARGING WITH THE DYNAMO . . . . . . 32

The dynamo. . . . . . . . . . . . 32

Dynamo output control . . . . . . . . 35

The third brush dynamo . . . . . . . . . 36

Compensated-voltage control . . . . . . . . 37

Current-voltage control . . . . . . . . . . 41

The cut out . . . . . . . . . . . . . 42

Dynamo maintenance .......... . . 43

Control unit maintenance . . . . . . . . . 44

Chapter 5: THE ALTERNATOR . . . . . . . . . . . 45

The principle of the alternator . . . . . . . . 45

The principle of the rectifier. . . . . . . . 47

Alternator output control . . . . . . . . . 49

The alternator relay and warning light ..... 51

Alternator mounting . . . . . . . . . 52

Integrated circuit regulator pack . . . . . . . 52

The motor cycle alternator . . . . . . . . 52

The 12 volt motor cycle alternator system . . . . . 54

The motor cycle alternator control system . . . . . 55

Chapter 6: SIMPLE IGNITION SYSTEMS . . . . . . 56

Ignition systems . . . . . . . . . . . 56

Coil ignition. . . . . . . . . . . 56

Electrical operation . . . . . . . . . 57

The coil ............... . . 58

Spark polarity . . . . . . . . . . . 59

The contact breaker and distributor ... . . 60

The condenser ............ . . 62

The contacts ............. 63

High tension leads . . . . . . . . . . . 64

The firing order . . . . . . . . . . 64

Ignition time ............ . . . . 65

Automatic advance and retard . . . . . . 66

Distributor maintenance . . . . . . . . . 67

The rotating-armature magneto . . . . . . . 68

The principle of the magneto . . . . . . 69

The rotating-magnet magneto . . . . . . . 70

Maintenance of magnetos . . . . . . . 71

Ignition test oscilloscope .......... 71 
Chapter 7: SPARKING PLUGS . . . . . . . . . . 72

Plug construction ............ 72

Sparking plug sizes .......... . . 73

Plug types. . . . . . . . . . . . . 74

Plug maintenance . . . . . . . . . . 76

Chapter 8: ADVANCED IGNITION SYSTEMS . . . . . . 78

The cold start ignition coil . . . . . . . . . . 78

Ignition using transistors . . . . . . . . . . . . 78

Transistor assisted contacts . . . . . . . 79

Electronic ignition . . . . . . . . . . . 81

The Lucas "Opus" electronic ignition system . . . . . 82

The photodiode ignition system . . . . . . . 83

The magnetic pulse ignition system . . . . . . 83

Piezo-electric ignition ... . . . . . . . 84

Chapter 9: STARTING SYSTEMS . . . . . . . . 85

The starter motor . . . . . . . . . . 85

Starter power . . . . . . . . . . 87

The starter drive . . . . . . . . . . . 87

The inertia engaged drive . . . . . . . . . . 88

Positive engaged drive . . . . . . . . . . . . 89

Inboard and outboard drive . . . . . . . . . 90

Starter maintenance . . . . . . . . . . 91

The starter switch . . . . . . . . . . 93

Chapter 10: LIGHTING . . . . . . . . . . . . 96

Headlamps ............ 96

The headlamp lens . . . . . . . . . . . 97

Earlier headlamps . . . . . . . . . . . . . . . 98

The light unit with pre-focus bulb . . . . . . . . 99

The light unit with asymmetric dipped beam . . . . . 101

The sealed beam unit . . . . . . . . . 102

The four headlamp system. . . . . . . . . . 103

Headlamp setting . . . . . . . . . . 105

Other external lamps . . . . . . . . . . . . . 107

Extra driving lamps . . . . . . . . . . 109

Lamp bulbs . . . . . . . . . . . . . 110

Tungsten halogen bulbs .......... 113

The effect of headlamp voltage variation . . . . 115 
Chapter 11: ELECTRICAL CONTROLS, INSTRUMENTS AND ACCESSORIES . . . . . . . . . . 117

The electric horn . . . . . . . . . . . . 117

The high frequence horn . . . . . . . . 118

The windtone horn . . . . . . . . . . 118

Horn mounting and operation . . . . . . . 119

Windscreen wipers........... 120

The cable rack windscreen wiper . . . . . . . . 122

The link windscreen wiper. . . . . . . . . . 124

Intermittent wiping . . . . . . . . 125

Windscreen washers .......... 126

Direction indication . . . . . . . . 127

Flashing light indicators . . . . . . . . . . 128

Two-level signals . . . . . . . . . . . 132

Brake and indicator lights for trailers . . . . . 132

Dimmed headlamps . . . . . . . . . 134

The dip switch . . . . . . . . . . . 137

Headlamp flashing . . . . . . . . . . . 138

Bonnet and boot lamps . . . . . . . . . . 138

Brake light switch . . . . . . . . . . 138

Courtesy lights . . . . . . . . . . . 139

Facia or panel lights . . . . . . . . . . . . 140

Warning lamps . . . . . . . . . . . 140

The electric petrol pump . . . . . . . . . 141

Electrically operated reserve petrol tap . . . . . . . 143

Instruments . . . . . . . . . . . . . . . 144

The moving iron-resistance fuel level indicator . . . . 144

The bimetal resistance fuel level indicator . . . . . . 146

Oil level indication . . . . . . . . . . . . 147

The thermal temperature indicator . . . . . . 148

The semiconductor temperature indicator . . . . . . 149

The oil pressure indicator . . . . . . . . . . 151

Oil pressure switches . . . . . . . . 151

The voltage stabiliser unit . . . . . . . 152

Vacuum gauges ............. 153

The ammeter ............ 153

The voltmeter . . . . . . . . . . 153

Air-cored instruments . . . . . . . . . 153

Moving-coil-generator speed indicators . . . . . 154

Electric clocks . . . . . . . . . . . . 154 
Interior heaters and ventilators . . . . . . 156

Demisting ............ 156

Air conditioning : . . . . . 156

Electric cooling fans . . . . . . . . . 157

Power operated windows . . . . . . . . 157

Electronic fuel injection . . . . . . . . . 157

The overdrive unit . . . . . . . . . 158

Eddy current brakes ........... 158

Chapter 12: RADIO EQUIPMENT . . . . . . . . . 160

The car radio . . . . . . . . . . . . 160

Coach equipment . . . . . . . . 162

The car tape recorder .......... . . 163

Two-way radio. . . . . . . . . . . 163

Car television ............. 163

The aerial . . . . . . . . . . . . . 164

Interference . . . . . . . . . . . . . . 164

Suppressing interference . . . . . . . 164

Chapter 13: ELECTRONIC EQUIPMENT IN CARS . . . . . 169

Transistor controlled flashing lights . . . . . 169

The use of photocells .......... 171

Rear light failure warning . . . . . . 171

Automatic anti-dazzle mirror . . . . . . 172

Automatic headlamp dipping . . . . . 173

The electric impulse tachometer . . . . . . . 174

Fluorescent lighting . . . . . . . . 175

Zener diode . . . . . . . . . . . . . . 177

Index ...................... 178 